\title{
Botryomycosis in a Buffalo
}

\author{
J.J.Parmar, B.G.Kag, P.B.Patel, H.C.Chauhan and V.K.Sharma
}

Teaching Veterinary Clinical complex Deesa, Veterinary College, Sardarkrushinagar Dantiwada Agricultural Unviersity, Sardarkrushinagar-385506, Gujarat, India.

* Corresponding author email : sharma.vksharma@yahoo.com

Published online 30-04-2011

\section{I ntroduction}

Botryomycosis is a chronic suppurtive infection characterized by granulomatous imflammatory lesions of generally cutaneous and less commonly of visceral origin due to involvement of becterial pathogens: Staphylococus aureus (Winslow, 1959). The occurence of disease is relatively uncommon and its description is limited to only few case reports in human beings (Aronstain, 1936 ; Pavitran, 1988 and Kadyan, 1994). However such imformation is not available in animals. Therefore, the present case is placed on record.

\section{Case History}

A three year old buffalo weighed approximately $350 \mathrm{~kg}$ was presented to the Teaching Veterinary Clinical Complex, Deesa with complaint of hard lesions over the face and neck without any sign of systemic illness since one year. The temperature, heart and respiration rates were well within the physiological limit.

Clinically, the lesions were tenderous, multiple and cutaneous type spreaded over the head and neck regions (Figure-1). The exploratory examination of lesions revealed presence of thick creamy pus which

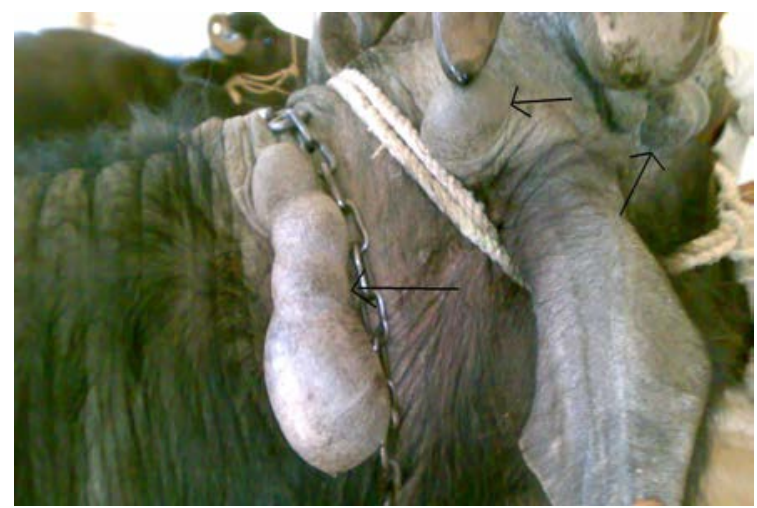

Figure-1. Affected Buffalo Showing Lesions of Disease Over Head and Neck. was collected in a sterile glass beaker. The pus was subjected to cultural isolation of organisms and antibiotic sensitivity test (Figure-2).

Treatment manuovers: The protruded part of most prominant nodules was incised from its base under xylazine sedation @ dose of $0.1 \mathrm{mg} / \mathrm{kg}$. The exudate was removed and sinus tract flushed with $1 \%$ solution of tincture iodine. The tract was packed subsequently with sterile gauge pieces of suitable size. Oxytetracycline, which was found most sensitive among other antibiotics on in- vitro sensitivity test, was infiltrated over the gauge piece. The similar treatment was continued for 5 days and other nodules / lesions were treated in the similar manner following healing of previous one. The parenteral administration of oxytetracycline @ dose of $5 \mathrm{mg} / \mathrm{kg}$ was also attempted for 5 days.

\section{Results and Discussion}

The nodules of variable size between 1.5-2.5 centimeter were present over the skin of face and neck including ears in the present case. The lesions were painless and tendorous in nature which were suggestive of subcutaneous tissue involvement. Winslow (1959) documented two forms of botryomycosis: cutaneous and pulmonary. The presence of multiple sinuses besides single or multiple abcess of skin and subcutaneous

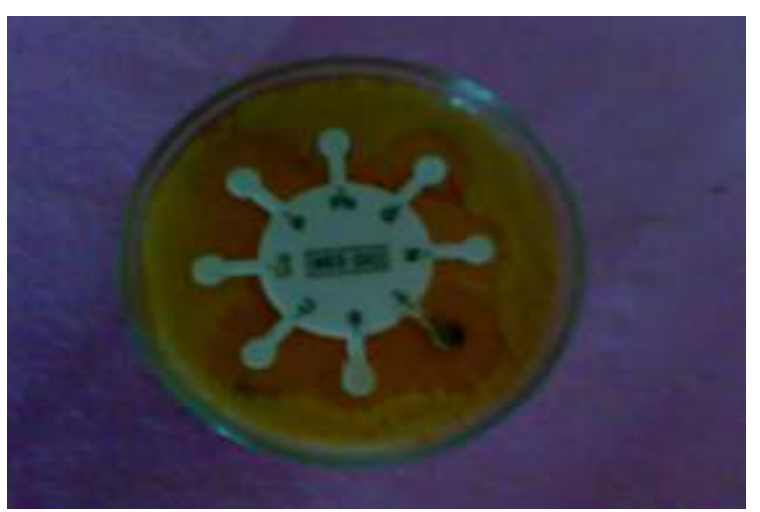

Figure-2. Antibiotic Sensitivity 
tissue additionally in cutaneous form of disease have been described by the author. In the present case, the characteristics of nodules with regard to body integuments, pus contents comfirmed the cutaneous form of disease which is an agreement with the earlier findings of Inamdar and Nagalotimath (1994). Further, the lesions of disease have been reported usually unresponsive to the medicinal therapy; as a result the petients are intervened for cure by the surgical approach. In the present case, also, removal of the pus from nodules was followed immediately by local and parenteral administration of most sensitive antibiotic which resulted in to complete recovery at faster rate.

\section{Summary}

A rare case of botryomycosis with its typical lesions abundantly on face, neck and ears is documented in the buffalo. The treatment consisting of surgical intervention followed by local and parenteral administration of most sensitive antibiotic has also been discussed.

\section{References}

1. Aronstain, N.E. (1936). Human botryomycosis with case report. Ind J Dermatol. 2:39 (Quoted in IJDVL cumulative index, supplement, 1994;601:10).

2. Inamdar, C.A. and Nagalotimath, S.J. (1994). Botryomycosis. Ind. J Dermatol Venereol Leprol 60:108109.

3. Kadyan, R.S. (1994). Botryomycosis - 2 case reports. VII International Congress of Dermatology, New Delhi, India, (Book of Abstracts).

4. Pavitran, K. (1988). Staphylococcal botryomycosis of the glans penis. Ind J Dermatol venereol leprol 54:216-7.

5. Winslow, D.J. (1959). Botryomycosis. Am J Pathol 35:153. 